\title{
Acute vision loss in Guillain-Barré syndrome: A case series and review of literature
}

\author{
Abhay Ranjan ${ }^{1 *}\left(\mathbb{0}\right.$, Ramdas Pandurangrao Solanke ${ }^{1}$, Neetu Sinha ${ }^{2}$ and Vidya Bhushan ${ }^{3}$
}

\begin{abstract}
Background: Acute vision loss in Guillain-Barré syndrome is rarely reported in literature. No case of vision loss in Guillain-Barré syndrome due to Angle closure glaucoma has been reported in AIDP variant GBS.

Case presentation: We report three patients with an acute inflammatory demyelinating polyradiculoneuropathy subtype of GBS who developed acute vision loss during the course of disease. Two patients had autonomic dysfunction with hypertension, in which one patient presented with painful acute vision loss and was diagnosed with Angle closure glaucoma and another patient had painless vision loss which was due to posterior reversible encephalopathy syndrome. Third patient presented with bilateral papilledema with raised cerebrospinal fluid protein and intracranial pressure. Vision in all the three patients improved after treatment.

Conclusion: Patient with GBS, with autonomic dysfunction and hypertension or elevated cerebrospinal fluid protein may present with acute vision loss during the course of the disease. Early diagnosis and management help to improve vision and prevent permanent vision loss in these patients.
\end{abstract}

Keywords: Guillain-Barré syndrome, Acute inflammatory demyelinating polyradiculoneuropathy, Angle closure glaucoma, Posterior reversible encephalopathy syndrome, Papilledema, Vision loss

\section{Introduction}

Guillain-Barre syndrome (GBS), an inflammatory disease of the peripheral nervous system, is rapidly progressive flaccid symmetrical weakness of upper and lower limbs with or without sensory or autonomic disturbances having a monophasic course of less than 4 weeks. GBS is the commonest cause of acute flaccid paraplegia with annual global incidence of approximately 1-2 per 100,000 person-year [1]. In India, acute inflammatory demyelinating polyradiculoneuropathy (AIDP) is the most common electrophysiological subtype of GBS, occurring in approximately three quarters of patients [2]. Patients with GBS typically present with weakness and sensory signs in the legs that progress to the arms and cranial muscles, although the clinical presentation of the

\footnotetext{
*Correspondence: drabhayranjan97@gmail.com

${ }^{1}$ Department of Neurology, Indira Gandhi Institute of Medical Sciences,

Sheikhpura, Patna, Bihar 800014 , India

Full list of author information is available at the end of the article
}

disease is heterogeneous and several distinct clinical variants exist [3]. Acute vision loss in GBS is rarely reported in the literature. We report three cases of GBS who had acute bilateral vision loss during their course of illness.

\section{Case presentation \\ Case \# 1}

A 44-year-old female presented to our outpatient department (OPD) with progressive weakness in all limbs for 4 days. Patient was hypertensive and has undergone laparoscopic cholecystectomy 10 days prior to onset of symptoms. On clinical examination, she had areflexic quadreperesis and Medical Research Council (MRC) sum score was 23/60. Nerve conduction study (NCS machine model-Model-Key Point, manufactured by Medtronic, Denmark, year of manufacture-2005) findings were suggestive of Acute inflammatory demyelinating polyradiculoneuropathy (AIDP) subtype of GBS. Cerebrospinal fluid (CSF) analysis showed albuminocytological dissociations $\{$ CSF protein $156.6 \mathrm{mg} / \mathrm{dl}$, cells: 
5 (all lymphocytes), glucose: $61 \mathrm{mg} / \mathrm{dl}$ (blood glucose: $96 \mathrm{mg} / \mathrm{dl})\}$. Within 4 days of admission, she developed breathing difficulty and was put on mechanical ventilation. She had autonomic dysfunction, accompanied by severe tachycardia (156 beats/min) which was controlled by metoprolol, and her pupils were equal on both sides and reacting to light. She was administered Intravenous Immunoglobulin (IV Ig) and gradually weaned off from ventilator after 2 weeks. Her MRC sum score improved to $42 / 60$. Two days later, she was weaned off ventilator; at night she had acute binocular diminished vision along with pain. At the time of onset of diminished vision, she could perceive hand movement and projection of light in both eyes, her pupils were mildly dilated and sluggishly reacting to light. The vision further deteriorated the next morning, the movement of the hand could be felt in the left eye but she could not perceive projection of light in the right eye. Direct and indirect pupillary reflexes were absent. A direct ophthalmoscope (Model: Beta 200 (2.5 V XHL); manufactured by Heine, Germany; year of manufacture: 2012.) examination of the fundus revealed bilateral corneal oedema and shallow anterior chamber (right $>$ left). On her tonometry, intraocular pressure was raised (right eye: $31 \mathrm{~mm}$ of $\mathrm{Hg}$ and left eye: $27 \mathrm{~mm}$ of $\mathrm{Hg}$ ). Slit lamp (Model: SL CAMICM7; manufactured by Appasamy Associates India; year of manufacture: 2018.) examination of both eyes showed mild corneal edema, shallow anterior chamber, and mid dilated irregular fixed pupil more on the left eye than right eye (Fig. 1). On the anterior segment optical coherence tomography (AS-OCT) [Model: DRI OCT Triton, manufactured by Topcon corporation, Tokyo, Japan. Year of manufacture: 2015], the angle of anterior chamber appeared narrow (less than $20^{\circ}$ ) (Fig. 2). Extraocular movements were normal. MRI (Model: Optima MR 360, manufactured by General Electric Company, country: Wisconsin, USA, year of manufacture: August 2016) of the brain with orbits showed bilateral tortuous optic nerves and dilated perioptic subarachnoid spaces. She was diagnosed to have bilateral angle-closure glaucoma (ACG) and was treated with intravenous mannitol and oral acetazolamide. After 3 days of treatment, the vision

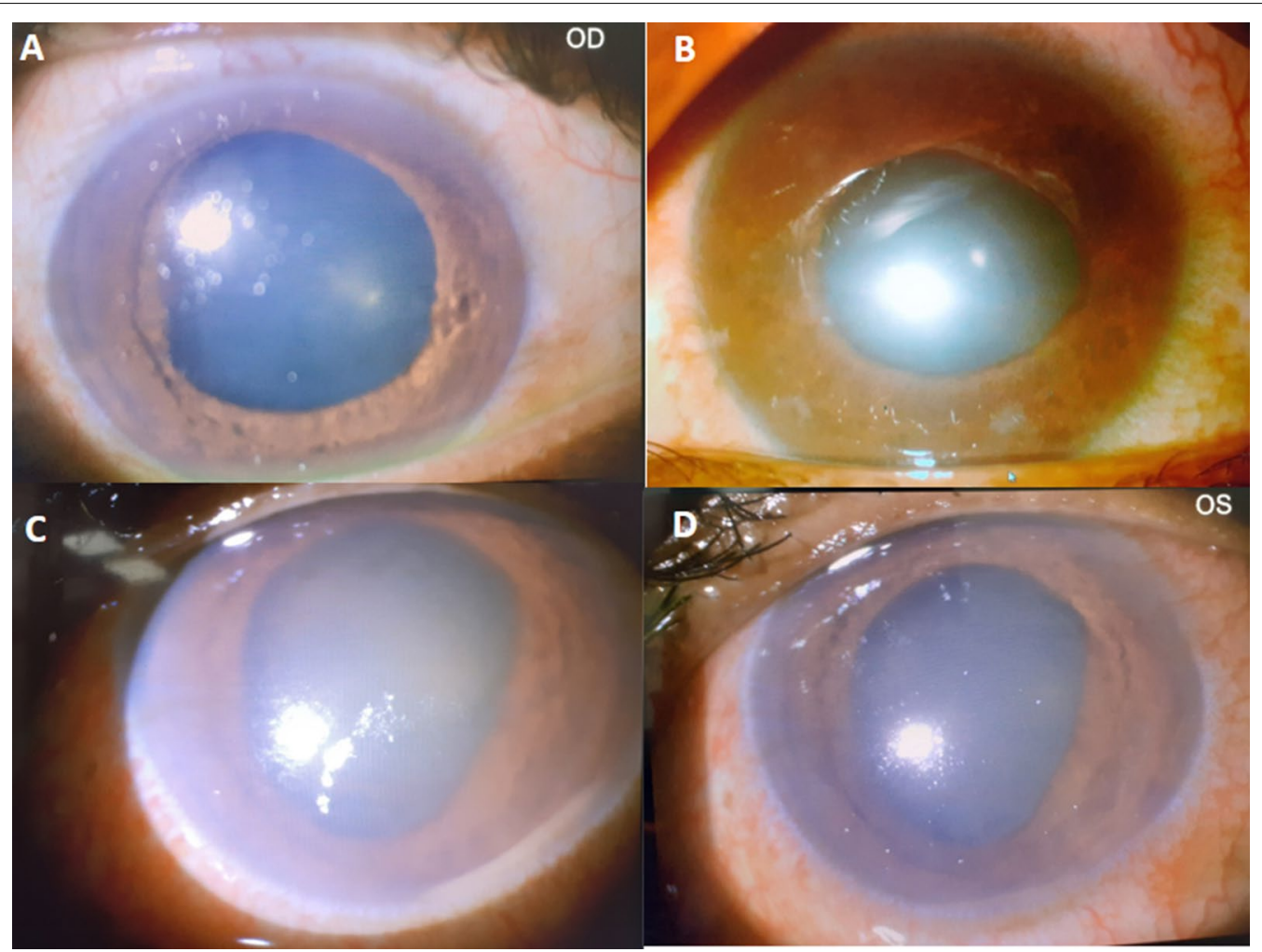

Fig. 1 Slit lamp image. A Before the treatment in Rt eye, mild corneal edema, shallow anterior chamber, mid dilated irregular fixed pupil with picking at 8 and $12 \mathrm{O}^{\prime}$ clock position was observed. B After the treatment, the cornea is clear, the pupils are smaller than before the treatment, the response to light is slow, and the sphincter is atrophy at 12-2 o clock position. Right eye after treatment revealed clear cornea, constricted pupil than before treatment and sluggish reaction to light, sphincter atrophy 12-2 o clock position. C Left eye before treatment demonstrates. Severe diffuse corneal edema with shallow anterior chamber, irregular pupil and posterior synechiae from 2 to 60 clock position. $\mathbf{D}$ Left eye after treatment showed improvement in corneal edema 


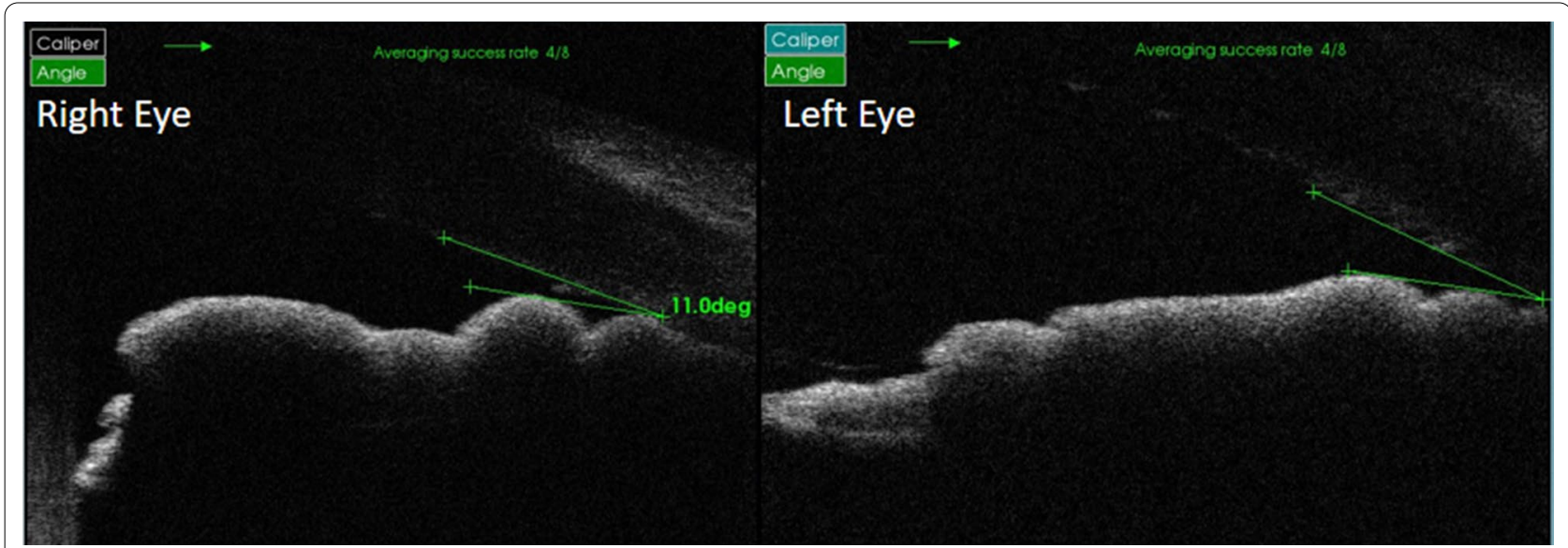

Fig. 2 AS-OCT (Anterior segment optical coherence tomography) images show Narrow Anterior Chamber less than 20 degree. (Grade 2 Shaffer's Grade)

in the left eye improved to a finger count at 3 feet, but the right eye could only perceive hand movement. On slit light examination, corneal edema decreased in both eyes. The patient underwent a trabeculectomy in the right eye for non-improvement, and his vision improved to a finger count at 2 feet. After 2 months her vision was $6 / 18$ in right eye and 6/12 in left eye.

\section{Case \# 2}

A 22-year-old lady presented to our OPD with a history of progressive weakness of both upper and lower limbs for 20 days. She was diagnosed as a case of GBS and was given IV Ig. The patient's weakness was improved and she was able to walk with slight support. Three days after
IV Ig, she again developed progressive weakness in all her limbs, accompanied by mild to moderate persistent holocranial headache and decreased binocular vision. On examination, MRC sum score was 30/60 with hypotonia and generalized areflexia. Nerve conduction studies showed findings of AIDP variant GBS. CSF study revealed albuminocytological dissociations (CSF: Protein $389.6 \mathrm{mg} / \mathrm{dl}$, cells 5 (all lymphocytes), glucose: $86 \mathrm{mg} / \mathrm{dl}$ (blood glucose: $105 \mathrm{mg} / \mathrm{dl}$ )\} with markedly raised protein $(389.6 \mathrm{mg} / \mathrm{dl})$ and CSF opening pressure was $280 \mathrm{~mm}$ of CSF. In the ophthalmological evaluation, her vision in both eyes was $6 / 18$, and her extraocular movements were normal. On fundoscopy she had grade IV papilledema in both the eyes (Fig. 3). MRI of brain and orbit revealed

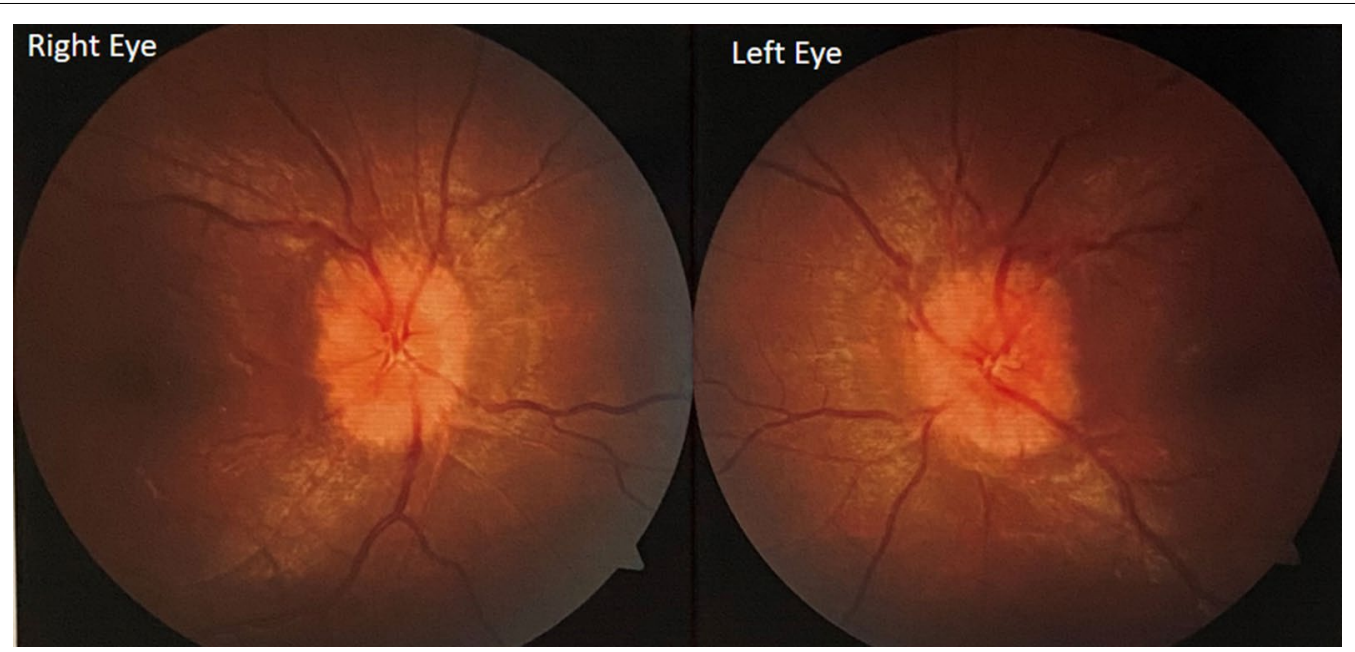

Fig. 3 Fundus of both eyes shows marked elevation of optic nerve head with obscuration of all border (blurring of disc margin) and filling of physiological cupping. Grade 3 (moderate) papilledema (FRISEN SCALE) 
distension of perioptic nerve sheath, vertical tortuosity and flattening of posterior sclera (Fig. 4). Patient was given IV Ig and oral acetazolamide. After 1 month of treatment her vision improved from $6 / 18$ to $6 / 6$ and MRC sum score improved to 50/60.

\section{Case \# 3}

A 40-year-old gentle man presented with complains of progressive weakness, tingling and paraesthesia of all limbs since past 7 days. MRC sum score of limbs was 28/60. He had bilateral facial and bulbar weakness. He was intubated and put on mechanical ventilation. $\mathrm{He}$ had dysautonomia with trachypnia, tachycardia and hypertension. Nerve conduction studies were suggestive of AIDP variant GBS. The CSF study showed albuminocytological dissociation (Protein $167 \mathrm{mg} / \mathrm{dl}$, cells $<5$ (all lymphocytes), glucose: $78 \mathrm{mg} / \mathrm{dl}$ (blood glucose: $102 \mathrm{mg} /$ dl)\}. He was given IVIg and extubated within 3 days. After 5 days of IV Ig treatment, he developed acute onset bilateral painless vision loss. On ophthalmic examination perception of light was absent in both eyes but pupils were reacting to light. Blood pressure in supine posture was $150 / 100 \mathrm{~mm}$ of mercury with no significant postural drop (she had blood pressure of 100/60 mm of $\mathrm{Hg}$ prior to illness). Magnetic resonance imaging (MRI) of brain revealed increased signal on T2W and FLAIR images in white mater of bilateral parieto-occipito-temporal region with patchy hyperintense signal on diffusion weighted image (DWI) (Fig. 5). He was diagnosed with posterior reversible encephalopathy syndrome (PRES) and was managed conservatively. After 7 days, he was able to count his finger at a distance of $6 \mathrm{~m}$. After 6 months, his binocular vision was 6/6. Power of limbs improved to MRC sum score of 44/60.

\section{Discussion}

Guillain-Bare syndrome is an immune mediated disorder of peripheral nervous system in which autonomic dysfunction is seen in up to two-thirds of patients in GBS which includes blood pressure fluctuations, arrhythmias, vasomotor dysfunction, and gastrointestinal (GI) motility dysregulation [3]. Few case reports associate autonomic dysfunction with GBS and acute bilateral vision loss such as posterior reversible encephalopathy syndrome (PRES) and angle closure glaucoma. There are also case reports of acute vision loss and papilledema in GBS.

There are few case reports of acute angle-closure glaucoma in Miller fisher Variant of GBS reported in literature. ACG is a common form of glaucoma in which the anterior chamber of eyeball is closed, and the aqueous drainage of the eye is blocked. First case of unilateral ACG with diminished visual acuity in GBS (Miller Fisher variant) was reported in 2006 [4].A case of MFS variant GBS with bilateral simultaneous ACG was described in a 55-year-old person who presented with bilateral blurred vision and unsteadiness [5]. Won Yeol Ryu, and colleagues reported a case of MFS without autonomic dysfunction who presented with right eye pain and blurred vision and was diagnosed as a case of acute ACG [6]. Blurred vision and eye pain can be a presenting complaint in MFS variant GBS associated ACG [7]. As far as we know, this is the first case of GBS AIDP variant with autonomic dysfunction due to ACG-induced vision loss on both sides (Table 1). The pathophysiology attributed

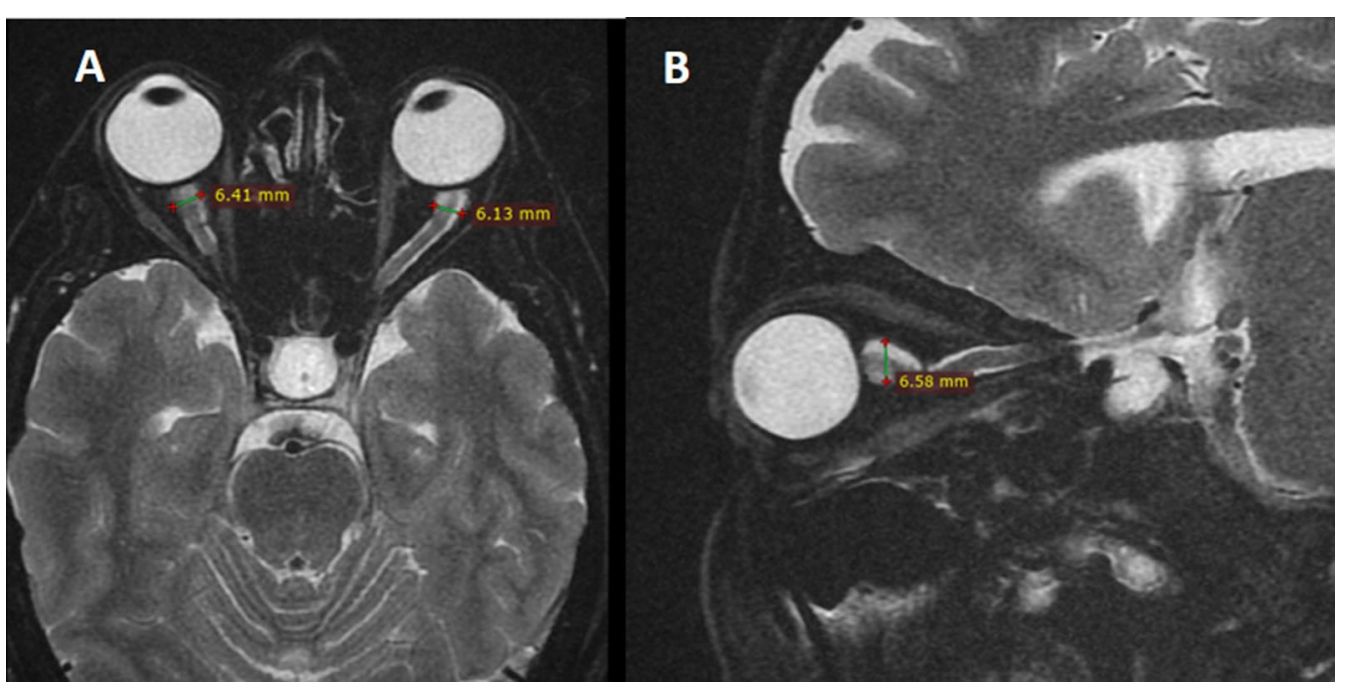

Fig. 4 A Axial T2 weighted fat saturated image of orbit demonstrates distension of perioptic sheath of bilateral optic nerve. B Sagittal T2 weighted fat saturated image of orbit demonstrates vertically tortuous of right optic nerve with distension of perioptic sheath and flattening of posterior sclera 


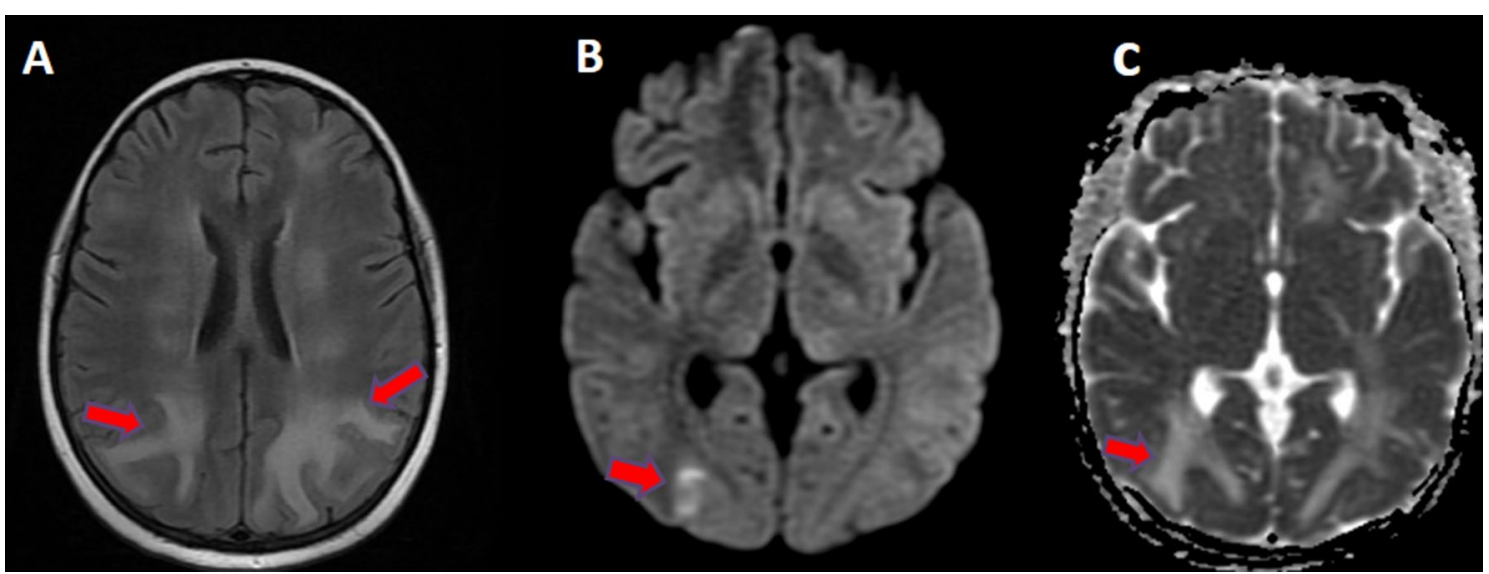

Fig. 5 A Axial FLAIR MRI image of brain demonstrates symmetrical hyperintense signal in white matter of bilateral parieto-occipital region with some cortical involvement (Red arrows). B, C Axial DWI and ADC image of brain demonstrates hyperintense signal in right occipito-temporal region (red arrows) with no corresponding decrease in ADC signal

Table 1 Summary of cases reported in literature of vision loss in GBS due to Angle closure glaucoma

\begin{tabular}{|c|c|c|c|c|c|}
\hline & Baxter JM et al. [5] & Han J et al. [7] & Ryu, W. Y. et al. [6] & Brittain CJ et al. [4] & Our case \\
\hline Variant of GBS & MFS & MFS & MFS & MFS & AIDP \\
\hline Age (years)/sex & 55/male & 78/female & 75/male & 64/male & 45/female \\
\hline Onset of vision loss & Presenting complaint & Presenting complaint & Presenting complaint & Presenting complaints & During recovery \\
\hline Laterality of symptoms & Bilateral & Unilateral (left eye) & Unilateral (Right Eye) & Unilateral (left eye) & Bilateral \\
\hline IOP at onset (RE and LE) & $\begin{array}{l}56 \mathrm{~mm} \text { of } \mathrm{Hg} \\
48 \mathrm{~mm} \text { of } \mathrm{Hg}\end{array}$ & $\begin{array}{l}18 \mathrm{~mm} \text { of } \mathrm{Hg} \\
48 \mathrm{~mm} \text { of } \mathrm{Hg}\end{array}$ & $\begin{array}{l}50 \mathrm{~mm} \text { of } \mathrm{Hg} \\
18 \mathrm{~mm} \text { of } \mathrm{Hg}\end{array}$ & $\begin{array}{l}20 \mathrm{~mm} \text { of } \mathrm{Hg} \\
56 \mathrm{~mm} \text { of } \mathrm{Hg}\end{array}$ & $\begin{array}{l}52 \mathrm{~mm} \text { of } \mathrm{Hg} \\
48 \mathrm{~mm} \text { of } \mathrm{Hg}\end{array}$ \\
\hline $\begin{array}{l}\text { BCVA at onset (RE and } \\
\text { LE) }\end{array}$ & $\begin{array}{l}\mathrm{HM} \\
6 / 18\end{array}$ & $\begin{array}{l}0.6 \\
P L\end{array}$ & RE- HM & $\begin{array}{l}6 / 9 \\
H M\end{array}$ & $\begin{array}{l}\mathrm{RE}-3 / 60 \\
\mathrm{LE}-6 / 60\end{array}$ \\
\hline ACD & Absent & Present & Present & Not Mentioned & Present \\
\hline CSF Proteins & Not given & $526 \mathrm{mg} / \mathrm{dl}$ & $53 \mathrm{mg} / \mathrm{dl}$ & Not given & $156.6 \mathrm{mg} / \mathrm{dl}$ \\
\hline Medical treatment & $\begin{array}{l}\text { Acetazolamide } \\
\text { Topical pilocarpine, } \\
\text { timolol and iopidine }\end{array}$ & $\begin{array}{l}\text { Mannitol } \\
\text { Topical timolol and } \\
\text { pilocarpine }\end{array}$ & $\begin{array}{l}\text { Mannitol } \\
\text { Topical Latanaprost, } \\
\text { Brinzolamide and } \\
\text { Timolol }\end{array}$ & $\begin{array}{l}\text { Acetazolamide } \\
\text { Topical Timolol, Latanap- } \\
\text { rost, lopidine }\end{array}$ & $\begin{array}{l}\text { Mannitol, } \\
\text { Acetazolamide } \\
\text { Topical timolol }\end{array}$ \\
\hline Surgical treatment & $\begin{array}{l}\text { Laser peripheral iri- } \\
\text { dotomy }\end{array}$ & None & $\begin{array}{l}\text { Laser peripheral } \\
\text { iridotomy }\end{array}$ & $\begin{array}{l}\text { Laser peripheral } \\
\text { iridotomy }\end{array}$ & $\begin{array}{l}\text { Laser peripheral } \\
\text { iridotomy }\end{array}$ \\
\hline IVlg therapy & Given & Given & Given & Given & Given \\
\hline $\begin{array}{l}\text { IOP after treatment } \\
\text { (RE and LE) }\end{array}$ & $\begin{array}{l}23 \mathrm{~mm} \text { of } \mathrm{Hg} \\
12 \mathrm{~mm} \text { of } \mathrm{Hg}\end{array}$ & $\begin{array}{l}18 \mathrm{~mm} \text { of } \mathrm{Hg} \\
20 \mathrm{~mm} \text { of } \mathrm{Hg}\end{array}$ & $\begin{array}{l}11 \mathrm{~mm} \text { of } \mathrm{Hg} \\
18 \mathrm{~mm} \text { of Hg }\end{array}$ & $\begin{array}{l}13 \mathrm{~mm} \text { of } \mathrm{Hg} \\
6 \mathrm{~mm} \text { of } \mathrm{Hg}\end{array}$ & $\begin{array}{l}19 \mathrm{~mm} \text { of } \mathrm{Hg} \\
16 \mathrm{~mm} \text { of } \mathrm{Hg}\end{array}$ \\
\hline $\begin{array}{l}\text { Time of Reassessment } \\
\text { after starting of treat- } \\
\text { ment }\end{array}$ & 6 months & 2 days & 2 days & 2 days & 2 months \\
\hline $\begin{array}{l}\text { BCVA after treatment } \\
\text { (RE and LE) }\end{array}$ & $\begin{array}{l}\text { RE-6/6 } \\
\text { LE-6/6 }\end{array}$ & $\begin{array}{l}\text { RE-0.8 } \\
\text { LE-0.6 }\end{array}$ & RE-10/20 & $\begin{array}{l}\mathrm{RE}-6 / 6 \\
\mathrm{LE}-6 / 6\end{array}$ & $\begin{array}{l}\mathrm{RE}-6 / 18 \\
\mathrm{LE}-6 / 12\end{array}$ \\
\hline
\end{tabular}

MFS Miller Fisher variant, AIDP acute inflammatory demyelinating polyradiculoneuropathy, $m m$ of $\mathrm{Hg}$ millimetre of mercury, $B C V A$ best corrected visual acuity, CSF cerebrospinal fluid, $I V I g$ intravenous immunoglobulins, $R E$ right eye, $L E$ left eye, $A C D$ albumin cytological dissociation, $I O P$ intra-ocular pressure, $H M$ hand movement, $P L$ perception of light, $R E$ right eye, $L E$ left eye

to ACG in MFS is due to oculomotor autonomic neuropathy leading to pupillary dilatation and narrowing or blockade of anterior chamber of eye $[4,5,7]$. Autonomic dysfunction can prolong in GBS and should be monitored even during subacute phase [8]. In our case
ACG occurred 2 weeks after onset of illness with autonomic dysfunction still persisting and on ophthalmologic examination there was decrease in the angle of anterior chamber of both eye, which might be due to oculomotor autonomic neuropathy, that led to increase in intraocular 
pressure and cornea oedema, which improved on follow up examination after managing ACG.

In previous literature, papilledema and its association with elevated CSF protein have been reported as a rare complication of GBS. A case of definite papilledema in GBS was first reported by Gilpin and colleagues [9]. In 1966 Morley JB and colleagues, reported a number of case reports and a case series describing papilledema and decreased vision in GBS [10]. Morley and colleagues reported 4 cases of GBS and papilledema who presented with headache and sensory-motor weakness of limbs. Most of the cases that are reported in literature, papilledema in GBS usually presents with headache and/ or diplopia and vision loss as a presentation is rare. Similar to our case, the literature describes the recurrence of GBS symptoms with decreased vision, headache, and bilateral papilledema after completing the first dose of IV Ig, which was managed by repeated IV Ig, intravenous mannitol and oral acetazolamide treatment [11]. Kharbanda P, S and colleagues, Mathis $\mathrm{S}$ and colleagues, Gross
FJ and colleagues. (in human immunodeficiency virus infection) and Hui-Jun Wen also reported decreased vision and increased intracranial pressure due to papilledema in GBS [12-15] (Table 2). The pathophysiology behind papilledema and headache is cerebral oedema caused by elevated CSF protein, and autopsy reveals swelling of nerve cells [16]. Similarly, in our case, there was increase in cerebrospinal fluid protein with increase in intracranial pressure, resulting in severe papilledema on both sides. IV Ig itself may cause aseptic meningitis, which may mimic pseudotumor cerebri (raised intracranial pressure) but in addition there is photophobia, fever, chills, positive Kernig's and Brudzinski's signs along with CSF showing an increased level of nucleated cells, high protein content and negative culture results [17]. In our case there was no fever or sign of meningeal irritation and CSF did not show raised cells and burring of vision was present.

PRES in GBS with acute vision loss is a rare complication of GBS reported in literature. PRES is a

Table 2 Summary of cases reported in literature of GBS with vision loss due to Papilledema

\begin{tabular}{|c|c|c|c|c|c|c|}
\hline & $\begin{array}{l}\text { Christina Doxaki } \\
\text { et al. [11] }\end{array}$ & $\begin{array}{l}\text { Kharbanda PS } \\
\text { et al. [12] }\end{array}$ & Mathis S et al. [13] & Gross FJ et al. [14] & Hui-Jun Wen [15] & Our case \\
\hline Variant of GBS & AIDP & AIDP & AIDP & AIDP & AIDP & AIDP \\
\hline Age (year)/ sex & 12/Female & 35/Female & 42/Male & 27/Female & $43 / f$ & 25/Female \\
\hline Visual symptoms & Diminished vision & Diminished vision & Diminished vision & $\begin{array}{l}\text { Transient visual } \\
\text { obscuration }\end{array}$ & $\begin{array}{l}\text { Blurred vision and } \\
\text { Deterioration of } \\
\text { near and distant } \\
\text { vision and diplopia }\end{array}$ & Diminished vision \\
\hline Headache & Present & Present & Absent & Not mentioned & Absent & Present \\
\hline $\begin{array}{l}\text { Signs of dysauto- } \\
\text { nomia }\end{array}$ & Present & Present & Absent & Not mentioned & Absent & Present \\
\hline $\begin{array}{l}\text { BCVA } \\
\text { (RE and LE) }\end{array}$ & $\begin{array}{l}\text { Reduced } \\
\text { Reduced }\end{array}$ & $\begin{array}{l}P L \\
P L\end{array}$ & $\begin{array}{l}\text { Reduced } \\
\text { Reduced }\end{array}$ & $\begin{array}{l}\text { RE-20/20 } \\
\text { LE- } 20 / 20 \\
\text { Enlarged blind spot }\end{array}$ & $\begin{array}{l}\text { RE-20/30 } \\
\text { LE- 20/25 }\end{array}$ & $\begin{array}{l}\text { RE-6/60 } \\
L E-6 / 60\end{array}$ \\
\hline Papilledema & Present & Present & Present & Present & Present & Present \\
\hline $\begin{array}{l}\text { Signs of raised ICP } \\
\text { on Neuroimaging }\end{array}$ & Not mentioned & Present & Not mentioned & Not mentioned & Normal & Present \\
\hline $\begin{array}{l}\text { CSF opening pres- } \\
\text { sure }\end{array}$ & $460 \mathrm{~mm}$ of CSF & $420 \mathrm{~mm}$ of CSF & 150 mm of CSF & $310 \mathrm{~mm}$ of CSF & Not Mentioned & $280 \mathrm{~mm}$ of CSF \\
\hline ACD (CSF Proteins) & Present & $\overline{(20 \mathrm{mg} / \mathrm{dl})}$ & Present (435 mg/dl) & Present (325 mg/dl) & Present (862 mg/l) & Present $(78 \mathrm{mg} / \mathrm{dl})$ \\
\hline IVIG therapy & Given & Given & Given & - & Given & Given \\
\hline $\begin{array}{l}\text { Other treatment } \\
\text { given }\end{array}$ & $\begin{array}{l}\text { Acetazolamide } \\
\text { Corticosteroid }\end{array}$ & $\begin{array}{l}\text { Acetazolamide } \\
\text { Corticosteroid }\end{array}$ & Not mentioned & Not mentioned & $\begin{array}{l}\text { Intravenous } \\
\text { Dexamethasone } \\
\text { and Mecobalamine }\end{array}$ & $\begin{array}{l}\text { Mannitol } \\
\text { Acetazolamide } \\
\text { Corticosteroid }\end{array}$ \\
\hline $\begin{array}{l}\text { Reassessment of } \\
\text { vision }\end{array}$ & After 2 months & Not mentioned & After 1 year & After $\sim 6$ months & 3 weeks & After 1 month \\
\hline $\begin{array}{l}\text { BCVA after treat- } \\
\text { ment }\end{array}$ & $\begin{array}{l}\mathrm{RE}-6 / 6 \\
\mathrm{LE}-6 / 6\end{array}$ & Not mentioned & $\begin{array}{l}\mathrm{RE}-6 / 6 \\
\mathrm{LE}-6 / 6\end{array}$ & $\begin{array}{l}\text { RE-20/20 } \\
\text { LE-20/20 } \\
\text { Blind spot normal } \\
\text { sized }\end{array}$ & $\begin{array}{l}\mathrm{RE}-6 / 6 \\
\mathrm{LE}-6 / 6\end{array}$ & $\begin{array}{l}\mathrm{RE}-6 / 6 \\
\mathrm{LE}-6 / 6\end{array}$ \\
\hline
\end{tabular}

GBS Guillain-Barré syndrome, AIDP acute inflammatory demyelinating polyradiculoneuropathy, $P L$ projection of light, $m m$ millimetre, $B C V A$ best corrected visual acuity, CSF cerebrospinal fluid, $I V I g$ intravenous immunoglobulin, $R E$ right eye, $L E$ left eye, $A C D$ albumin cytological dissociation, $I C P$ intracranial pressure, $R E$ right eye, LE left 
Table 3 Summary of cases reported in literature of GBS with vision loss due to PRES

\begin{tabular}{|c|c|c|c|c|c|}
\hline & Ramakrishnan et al. [23] & Chen A et al. [21] & Nabi S et al. [24] & Joshi S et al. [22] & Our case \\
\hline Variant of GBS & AIDP & AMAN & Not Mentioned & AIDP & AIDP \\
\hline Age(year)/sex & 12/Female & 63/Female & 17/Female & 69yrs/female & 40/Male \\
\hline BCVA (RE and LE) & $\begin{array}{l}\text { RE-PL Present } \\
\text { LE-PL absent }\end{array}$ & $\begin{array}{l}\text { Reduced } \\
\text { Reduced }\end{array}$ & HM Present 6/36 & 6/18 bilaterally & $\begin{array}{l}\text { PL absent } \\
\text { PL absent }\end{array}$ \\
\hline $\begin{array}{l}\text { Other features of dysauto- } \\
\text { nomia }\end{array}$ & $\begin{array}{l}\text { Hypertension } \\
(140 / 90 \mathrm{~mm} \text { of } \mathrm{Hg})\end{array}$ & $\begin{array}{l}\text { Hypertension } \\
(172 / 98 \mathrm{~mm} \text { of } \mathrm{Hg})\end{array}$ & $\begin{array}{l}\text { Hypertension } \\
\text { (160/100 mm of Hg) } \\
\text { Tachyacrdia-bradycardia }\end{array}$ & $\begin{array}{l}\text { Hypertension } \\
(210 / 100 \mathrm{~mm} \text { of Hg) }\end{array}$ & $\begin{array}{l}\text { Hypertension } \\
\text { (150/100 mm of Hg) } \\
\text { Tachycardia } \\
\text { Bladder dysfunction }\end{array}$ \\
\hline Seizure & Present & Present & Present & Present & Absent \\
\hline Neuroimaging showing PRES & Present & Present & Present & Present & Present \\
\hline ACD (CSF Protein) & Present (not mentioned) & Present $(59 \mathrm{mg} / \mathrm{dl})$ & Present (63 mg/dl) & Present (67 mg/dl) & Present (167 mg/dl) \\
\hline IVlg therapy & Given & Given & Given & Given & Given \\
\hline Reassessment done & After 1 month & After 10 months & 6 weeks & 3 months & After 6 months \\
\hline $\begin{array}{l}B C V A \text { at reassessment (RE } \\
\text { and } L E \text { ) }\end{array}$ & $\begin{array}{l}\mathrm{RE}-6 / 6 \\
\mathrm{LE}-6 / 6\end{array}$ & $\begin{array}{l}\mathrm{RE}-6 / 6 \\
\mathrm{LE}-6 / 6\end{array}$ & $\begin{array}{l}\mathrm{RE}-6 / 6 \\
\mathrm{LE}-6 / 6\end{array}$ & $\begin{array}{l}\mathrm{RE}-6 / 6 \\
\mathrm{LE}-6 / 6\end{array}$ & $\begin{array}{l}\mathrm{RE}-6 / 6 \\
\mathrm{LE}-6 / 6\end{array}$ \\
\hline
\end{tabular}

GBS Guillain-Barré syndrome, AIDP acute inflammatory demyelinating polyradiculoneuropathy, $A M A N$ acute motor axonal polyneuropathy, $P L$ projection of light, $H M$ hand movement, $m m$ millimetre, $H g$ mercury, $m g$ milligram, $d l$ decilitre, BCVA vest corrected visual acuity, CSF cerebrospinal fluid, $I V I g$ intravenous immunoglobulin, $R E$ right eye, $L E$ left eye, $A C D$ albuminocytological dissociation

clinicoradiological syndrome defined by the presence of headache, altered mentation, seizures, visual dysfunction and focal neurological deficits [18]. PRES in GBS may occur due to disease itself or its treatment (IV Ig) or it can precede the onset of GBS in few cases $[19,20]$. In a review article on GBS and PRES, 13 such cases were described. In the review, about $92 \%$ of patients were female with average age of 63 years, $70 \%$ of patients had GBS symptoms prior to PRES, all the patient were hypertensive at the time of presentation and most of the patient were managed with IV Ig [21]. Similarly, our patient had symptoms of GBS before PRES, had autonomic dysfunction and hypertension at the time of presentation, and received IV Ig. Regardless of the review, our patient was male and of younger age (40 years vs 63 years). Most of the PRES cases in GBS reported in the literature, presented with headache, epilepsy, and/or encephalopathy. Reports of vision loss in PRES and GBS are rare [21-24] (Table 3). A case of GBS with PRES was recently reported, in which the symptoms of headache and decreased vision (PRES) preceded the symptoms of GBS [25]. Most widely accepted theory behind pathophysiology of PRES is breakdown of cerebral autoregulation due to a rapid rise in blood pressure leading to disruption of the blood-brain barrier. The exact mechanism of PRES in GBS is still unknown but the proposed mechanism for PRES in GBS include autonomic dysfunction and impaired cerebral autoregulation due to increase in blood pressure leading to raised cerebral blood flow and vasogenic oedema [26]. In our case also she had a blood pressure of $100 / 60 \mathrm{~mm}$ of $\mathrm{Hg}$ in supine posture prior to the illness. During the course of illness due to dysautonomia there was a sudden rise in blood pressure to $150 / 100 \mathrm{~mm}$ of $\mathrm{Hg}$ leading to failure of cerebral autoregulation, resulting in PRES. In literature, PRES in MFS without autonomic dysfunction have been reported as a complication of IV Ig associated with or without hypertension [27, 28]. However, in our case, autonomic dysfunction was present prior to start of IV Ig treatment, but additional effect of IV Ig on increased blood pressure could not be ruled out.

\section{Conclusions}

In patient of GBS with autonomic dysfunction and hypertension with bilateral diminished vision, the possibility of angle closure glaucoma should be considered if it is associated with eye pain, In a GBS patient with autonomic dysfunction, hypertension and bilateral vision loss, if accompanied by eye pain, the possibility of angle-closure glaucoma should be considered. And if it is not associated with eye pain, the possibility of PRES should be considered. In GBS without autonomic dysfunction, but with decrease vision and raised CSF protein, the possibility of increased intracranial pressure and papilledema should be strongly considered. Prompt diagnosis and management help in complete or near complete improvement in vision and prevents permanent vision loss.

\section{Abbreviations}

GBS: Guillain-Barré syndrome; AIDP: Acute inflammatory demyelinating polyradiculoneuropathy; ACG: Angle closure glaucoma; CSF: Cerebrospinal fluid; MRC: Medical Research Council; OPD: Outpatient Department; IV Ig: Intravenous immunoglobulins; MRI: Magnetic resonance imaging; PRES: Posterior reversible encephalopathy syndrome; MFS: Miller Fisher variant. 


\section{Acknowledgements \\ None.}

\section{Authors' contributions}

AR: concept, interpretation, writing and editing of manuscript; RPS: data collection, writing of manuscript; NS: data collection, interpretation of radiological data and editing of manuscript; VB: data collection and interpretation of ophthalmological data. All authors read and approved the final manuscript.

\section{Funding}

The authors declare that no financial support has been taken to conduct the research and/or preparation of the article.

\section{Availability of data and materials}

All data is provided in full in the results section of this paper.

\section{Declarations}

\section{Ethics approval and consent to participate}

Informed written consent of participants/their parent taken.

\section{Consent for publication}

Written informed consent to publish this information was obtained from study participant.

\section{Competing interests}

The authors declare that they have no competing interests.

\section{Author details}

'Department of Neurology, Indira Gandhi Institute of Medical Sciences, Sheikhpura, Patna, Bihar 800014, India. ²Department of Radiology, Indira Gandhi Institute of Medical Sciences, Patna, Bihar, India. ${ }^{3}$ Regional Institute of Ophthalmology, Indira Gandhi Institute of Medical Sciences, Patna, Bihar, India.

\section{Received: 4 October 2021 Accepted: 13 February 2022}

Published online: 07 March 2022

\section{References}

1. Sejvar JJ, Baughman AL, Wise M, Morgan OW. Population incidence of Guillain-Barré syndrome: a systematic review and meta-analysis. Neuroepidemiology. 2011;36(2):123-33.

2. Kalita J, Misra UK, Goyal G, Das M. Guillain-Barré syndrome: subtypes and predictors of outcome from India. J Peripher Nerv Syst. 2014;19(1):36-43.

3. Leonhard SE, Mandarakas MR, Gondim FAA, Bateman K, Ferreira MLB, Cornblath DR, et al. Diagnosis and management of Guillain-Barré syndrome in ten steps. Nat Rev Neurol. 2019;15(11):671-83.

4. Brittain CJ, Lake D. Acute angle closure in Miller Fisher syndrome. Eye (Lond). 2006:20:739-40.

5. Baxter JM, Alexander P, Maharajan VS. Bilateral, acute angle-closure glaucoma associated with Guillain-Barre syndrome variant. BMJ Case Rep. 2010;21(2010): bcr1120092487.

6. Ryu WY, Kim JK, Jin SW, Shim DH. Acute angle-closure glaucoma in a patient with miller fisher syndrome without pupillary dysfunction. J Glaucoma. 2015;24(2):e5-6.

7. Han J, Ji Y, Cao D, Kang Z, Zhu J. Miller Fisher syndrome with acute angleclosure glaucoma as the first manifestation: a case report. Medicine (Baltimore). 2017;96(50): e9201.

8. Rawat N, Khanna M, Rukmani R, Haldar P. Autonomic dysfunction in patients with Gullain-Barre syndrome in sub-acute phase. J Clin Diagn Res. 2019;13(6):LC16-20.

9. Gilpin S, Moersch FP, Kernohan JW. Polyneuritis: a clinical and pathologic study of a special group of cases frequently referred to as instances of neuronitis. Arch Neurol Psych. 1936;35(5):937-63.

10. Morley JB, Reynolds EH. Papilloedema and the Landry-Guillain-Barre syndrome. Case reports and a review. Brain. 1966;89(2):205-22.

11. Doxaki C, Papadopoulou E, Maniadaki I, Tsakalis NG, Palikaras K, Vorgia P. Case report: intracranial hypertension secondary to Guillain-Barre syndrome. Front Pediatr. 2021;8: 608695.
12. Kharbanda PS, Prabhakar S, Lal V, Das CP. Visual loss with papilledema in Guillain-Barre syndrome. Neurol India. 2002;50(4):528-9.

13. Mathis S, Le Masson G, Soulages A, Duval F, Solé G, Boissonnot $M$, et al. Papilledema and peripheral neuropathies. Neurologist. 2019:24(6):185-93.

14. Gross FJ, Mindel JS. Pseudotumor cerebri and Guillain-Barré syndrome associated with human immunodeficiency virus infection. Neurology. 1991;41(11):1845-6.

15. Wen HJ. Acute bilateral vision deficit as the initial symptom in GuillainBarre syndrome: a case report. Exp Ther Med. 2018;16(3):2712-6.

16. Joynt RJ. Mechanism of production of papilledema in the Guillain-Barre syndrome. Neurology. 1958;8(1):8-12.

17. Jain RS, Kumar S, Aggarwal R, Kookna JC. Acute aseptic meningitis due to intravenous immunoglobulin therapy in Guillain-Barré syndrome. Oxf Med Case Rep. 2014;2014(7):132-4.

18. Fischer M, Schmutzhard E. Posterior reversible encephalopathy syndrome. Med Klin Intensivmed Notfmed. 2016;111:417-24.

19. Bavikatte G, Gaber T, Eshiett MU. Posterior reversible encephalopathy syndrome as a complication of Guillain-Barré syndrome. J Clin Neurosci. 2010;17:924-6.

20. Elahi A, Kelkar P, St Louis EK. Posterior reversible encephalopathy syndrome as the initial manifestation of Guillain-Barré syndrome. Neurocrit Care. 2004;1:465-8.

21. Chen A, Kim J, Henderson G, Berkowitz A. Posterior reversible encephalopathy syndrome in Guillain-Barré syndrome. J Clin Neurosci. 2015;22(5):914-6.

22. Joshi S, Prentice D, van Heerden J, Chemmanam T. Guillain-Barré syndrome and posterior reversible leukoencephalopathy syndrome: a rare association. BMJ Case Rep. 2020;13(4): e234184.

23. Ramakrishnan S, Kannan B, Kannan A, Venkatesan EP. Vision loss in Guillain-Barre syndrome: is it a complication of Guillain-Barre syndrome or just a coincidence? J Ophthalmic Vis Res. 2016;11(3):340-1.

24. Nabi S, Rajput HM, Badshah M, Ahmed S. Posterior reversible encephalopathy syndrome (PRES) as a complication of Guillain-Barre' syndrome (GBS). BMJ Case Rep. 2016;2016: bcr2016216757.

25. Hinchey J, Chaves C, Appignani B, Breen J, Pao L, Wang A, et al. A reversible posterior leukoencephalopathy syndrome. N Engl J Med. 1996:334(8):494-500

26. Blackburn D, Chavada G, Dunleavy D, Hoggard N, Sharrack B, Ponnusamy $\mathrm{S}$, et al. Guillain-Barre syndrome (GBS) presenting with posterior reversible encephalopathy syndrome. J Neurol Neurosurg Psychiatry. 2011;82:

27. Nakajima M. Posterior reversible encephalopathy complicating intravenous immunoglobulins in a patient with miller-fisher syndrome. Eur Neurol. 2005;54(1):58-60.

28. Ribeiro BN, Salata TM, Borges RS, Marchiori E. Posterior reversible encephalopathy syndrome following immunoglobulin therapy in a patient with Miller-Fisher syndrome. Radiol Bras. 2016;49(1):58-9.

\section{Publisher's Note}

Springer Nature remains neutral with regard to jurisdictional claims in published maps and institutional affiliations. 